\title{
PERSPECTIVES OF VEGETABLE PRESSED SKINS PROCESSING AND USE IN FOOD INDUSTRY
}

\author{
Aleksandr Cherevko ${ }^{1}$ \\ process229@uk.net \\ Valeriy Mykhaylov ${ }^{I}$ \\ mykhailov@kharkov.com \\ Olga Mayak \\ omayak777@gmail.com \\ Andrey Shevchenko ${ }^{1}$ \\ andshev.hduht@ukr.net \\ Svitlana Prasol ${ }^{1}$ \\ process229@uk.net \\ Aziz Sardarov $^{1}$ \\ sardarov.aziz@gmail.com \\ ${ }^{1}$ Department of processes and equipment of food and hotel and restaurant industry named of \\ M. I. Belyaev \\ Kharkiv State University of Food Technology and Trade \\ 333 Klochkivska str., Kharkiv, Ukkraine, 61051
}

\begin{abstract}
Vegetable concentrates contain in their composition dietary fibers, microelements, color-forming substances, allowing to use them as a replacer of a main substance in food products rather successfully. The authors propose a way of vegetables processing into vegetable semi-products. Vacuum drying of vegetable pressed skins using vibration is provided.

The method of vegetables processing into vegetable concentrates on an example of carrot provides raw material separation in juice and pressed skin with further separate processing of each component.

For realizing the proposed method, a technological production line of concentrates of vegetable raw materials, including developed and studied equipment: vacuum evaporating apparatus with a device for heating and mixing, vacuum vibration dryer has been developed.

Experimental studies of a swelling degree, solubility and reproduction of vegetable pressed skins have proved an advantage of drying raw materials under the influence of vibration that confirmed the choice of process parameters. Vegetable pressed skins at using vibration and vacuum have a swelling degree by $120 \ldots 170 \%$ more than at the convection drying regime.
\end{abstract}

Keywords: carrot pressed skins, vacuum vibration drying, reproduction, solubility.

DOI: $10.21303 / 2504-5695.2021 .001633$

\section{Introduction}

The problem of rational use of natural resources exists in the world. Harvests of such crops as tomato, carrot, beetroot, wheat, potato and other depend on many conditions and need great capital investments. At that there are food products that are waste ones. For example, vegetable pressed skins. These raw materials remain after sugar production, production of juices, medical extracts and so on. And perspectives of using them are rather wide: as a coloring agent, structure-former, food supplement, baking powder, replacer of a main more expensive recipe raw material [1]. The plant crops, listed above, are a base of most food products. Their partial replacement for vegetable pressed skins will solve a series of questions - resource saving of raw materials, utilization of veg- 
etable pressed skins as a filler that gives a product certain properties, increases its food value and so on $[2,3]$.

Due to the fact that pressed skins are a material, spoiling rather fast, a scientific-applied question, connected with elaboration of a necessary complex of technological methods and equipment for processing them gains topicality.

Work [4] describes processing ways, studies regimes and influence of drying on preservation of biologically active substances and color-forming components of beetroot. Authors of work [5] proposed a new unique technology of vegetable raw materials processing in semi-products with an increased biological value. At that questions as to complex use of obtained products remains unsolved. A variant of overcoming correspondent complications may be the use of the system approach to raw materials processing, namely to use a vacuum technology at different processing stages for preserving most nutritive substances. That is pressed skins must be processed using certain temperatures (up to $55^{\circ} \mathrm{C}$ ) without air access. Just this approach was used in work [6], but the described processing way can be used only for liquid fractions. All this allows to state that it is expedient to conduct a research, devoted to elaboration of a complex little-waste processing way for vegetable raw materials using the vacuum technology.

Work [7] confirms the expedience of using concentrated fruit and berry pastes in recipes of confectionary products on an example of zephyr. It will provide consumers with food products with physiological and functional ingredients of natural origin. So, further use of obtained concentrated raw materials as a replacer of main recipe components is of scientific interest.

2 Materials and methods of studying solubility and reproduction of pressed skins from vegetable raw materials

Among quality parameters, determining consumption and technological properties of dry products are solubility degree and swelling degree in a soaking liquid. A swelling degree means a ratio of the wet product mass $m_{w}$ (after swelling during time $\tau$ ) to the initial dry product mass $m_{d}$ :

$$
Q=\frac{m_{w}}{m_{d}} \cdot 100 \%
$$

The solubility degree of samples was determined by the formula:

$$
D=\frac{m_{d}}{m_{n}} \cdot 100 \%=\frac{m_{d}-m_{n}}{m_{n}} \cdot 100 \%,
$$

where $m_{d}$ - mass of the part of a sample, dissolved in time $\tau, \mathrm{kg} ; m_{n}$ - mass of the part of a sample, not dissolved in time $\tau, \mathrm{kg}$.

Solubility and swelling degrees were determined for vegetable pressed skins, dried in an experimental vibration vacuum dryer at different regimes of raw materials processing, namely with a changing amplitude $(A, \mathrm{~m})$ and frequency $(v, \mathrm{~Hz})$. The fixed amount of a raw material $\left(m_{d}\right)$ was poured by the fixed amount of water and kept during $15 \mathrm{~min}(\tau)$. After that water was poured off and the wet product mass was determined $\left(m_{w}\right)$. The wet sample was placed in a drying chamber, dried, and its mass was determined. The obtained mass is one of the product part, not dissolved in time $\tau\left(m_{n}\right)$. The mass of the sample part, dissolved in time $\tau$ was determined as a difference between the initial mass $\left(m_{c}\right)$ and the mass of the sample part, not dissolved in time $\tau\left(m_{n}\right)$ [8].

The aim of the work is to elaborate a processing method for vegetable pressed skins with a possibility of their further use in food products.

The following tasks were solved for attaining this aim: 
- to elaborate a processing method for vegetable concentrate of carrot;

- to design a production line;

- to develop a construction of a vacuum vibration dryer;

- to study the solubility and reproduction of obtained dried pressed skins.

\section{Experiments}

There is offered the production method for vegetable concentrates on an example of carrot, including the following main stages: preparation of vegetable raw materials, comminution, separation of the mass in juice and pressed skins, juice filtration, juice concentrating to the content of dry substances $C_{\text {d.s. }}=70 \%$ by boiling under vacuum, comminution of pressed skins after juice separation, their drying to the content of dry substances $C_{\text {d.s. }}=90 \%$ under conditions of vacuumization and vibration influence, further use of concentrated juice and dried pressed skins according to the set technological tasks.

For producing vegetable concentrate by the offered way, the streaming technological line has been designed (Fig. 1). The main material, used in the researches, was carrot of the "Carrotel" sort. Completely ripen roots were selected. The main raw material corresponded to requirements of existing standards and technical conditions.
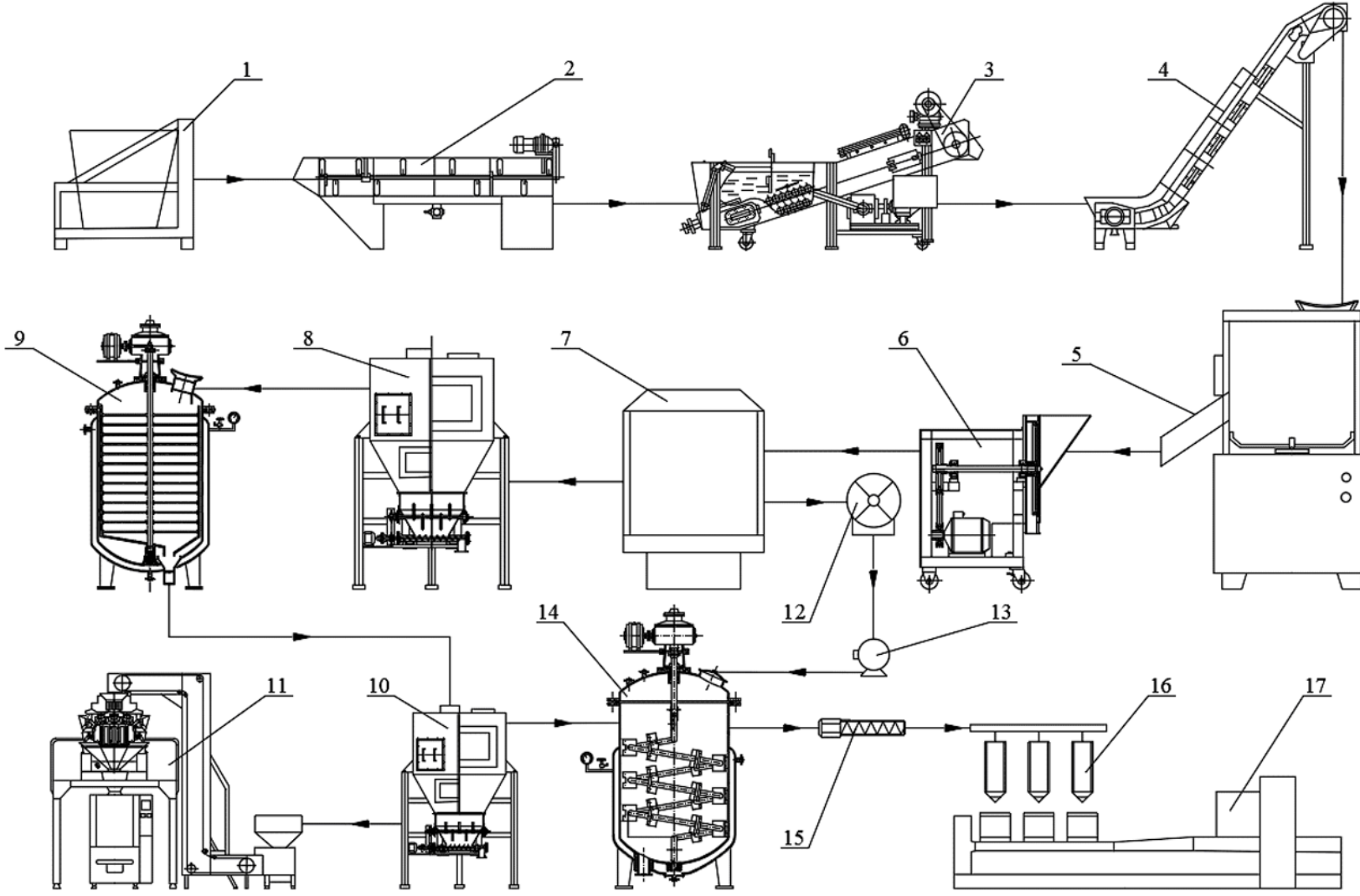

Fig. 1. Technological line of a concentrated product: 1 - container-tipper; blade washing machine; 3 - linear washing machine; 4 - transporter; 5 - machine for cleaning raw materials; 6 - vegetable slicer; 7 - apparatus for raw materials separation; 8 -technological bunker for raw materials with an auger metering device; 9 - vacuum vibration dryer; 10 - technological bunker for a dried product with an auger metering device; 11 - complex system for dosing-packing of ready products; 12 - vacuum filter; 13 - pump; 14 - vacuum-evaporating apparatus with an

improved device for mixing and heating; 15 - auger supercharger; 16 - metering device;

17 - apparatus for package 
For realizing the process of vegetable pressed skins vacuum drying under conditions of vibration field effect, the vibration vacuum dryer has been developed (Fig. 2).

The process of dehydration in the vibration vacuum dryer is realized by the following way: vegetable raw materials are loaded by hand in the working vacuum chamber and fixed on the spindle, fixed to the vibration generator, fixed to the apparatus cover and connected to the engine. Vacuum in the working chamber is provided by a branch pipe, a heating agent is supplied through it in the steam envelope for heating the working chamber, condensate is removed through the branch pipe. For measuring and controlling pressure in the vacuum dryer, an electric contact manometer has been fixed.

A technical result, achieved at using the developed apparatus is: shortening of the drying process by vacuuming; quality increase of a ready product by the low temperature regime; intensification of the drying process by using vibration for renewing the mass-exchanging surface of phase contact.

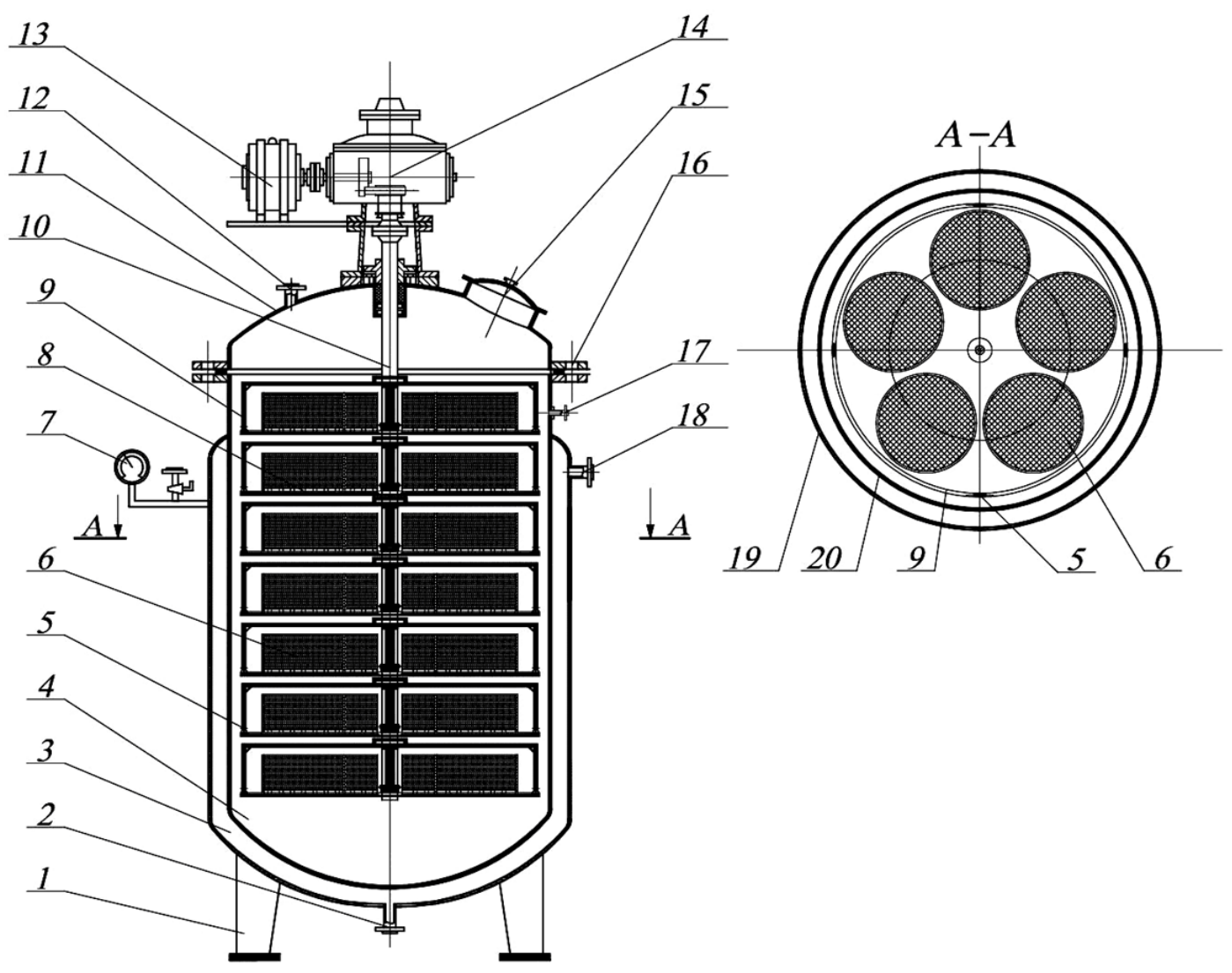

Fig. 2. Vibration vacuum dryer of periodic effect for drying pressed skins of raw materials: 1 - bearings 2 - branch pipe for heating agent removal; 3 - steam envelope; 4 - working chamber; 5 - fixing elements; 6 - perforated pans for raw materials; 7 - manometer; 8 - channels for moisture removal; 9 -concaves for a product; 10 - spindle; 11 - apparatus cover; 12 - technological branch pipe; 13 - engine; 14 - vibration generator; 15 - observation hatch; 16 - fixing joints; 17 - branch pipe for air removal from the working chamber; 18 - technological branch pipe for heating agent supply; 19 - walls of steam envelope; 20 - working chamber walls

The complex quality estimation of obtained dried pressed skins has been conducted [9].

As far as the use of dried pressed skins as a filler and improver of food products is provided, the studies of their swelling and solubility degree after drying have been conducted [10]. 
The results of the experimental studies of the vegetable pressed skins' swelling and solubility degree after the drying process in the vibration vacuum dryer at different drying regimes (Table 1) were calculated by formulas (1) and (2), respectively, presented in Table 2.

One of main quality characteristics of processed pressed skins is a solubility degree, which index characterizes the presence of active healthy components preserved in samples of products despite processing duration at drying.

Table 1

Drying regimes of vegetable pressed skins

$\begin{array}{cccc}\text { Name } & \text { Amplitude, } \mathbf{m} & \text { Frequency, } \mathbf{H z} & \text { Pressure, } \mathbf{M P a} \\ \text { Regime 1 } & 0 & 0 & 0.09 \\ \text { Regime 2 } & 0.005 & 6 & 0.09 \\ \text { Regime 3 } & 0.005 & 8 & 0.09 \\ \text { Regime 4 } & 0.009 & 6 & 0.09 \\ \text { Regime 5 } & 0.009 & 8 & 0.09\end{array}$

Table 2

Swelling and solubility of pressed skins from vegetable raw materials depending on drying regimes

\begin{tabular}{cccccc}
\hline Study & Regime 1 & Regime 2 & Regime 3 & Regime 4 & Regime 5 \\
\hline Swelling degree of carrot pressed skins. $Q \pm 0.01 . \%$ & 9.8 & 17.4 & 22.3 & 19.9 & 24.2 \\
Solubility degree of carrot pressed skins. $D \pm 0.01 . \%$ & 0.11 & 0.47 & 0.61 & 0.54 & 0.64
\end{tabular}

Fig. 3 presents graphs of reproduction kinetics of carrot pressed skins depending on process parameters according to Table 1. For comparing, the graphs present curve 1, characterized by a control sample, namely dried carrot pressed skins without a vibration influence.

According to the results of studying the reproduction kinetics of carrot pressed skins, the following conclusions may be made: a swelling type of pressed skins is equal, it grows proportionally to the amplitude and vibration frequency increase that is explained by the increase of the mass-exchanging surface at drying and fluffing of pressed skins that, in its turn, increases the structure porosity.

Fig. 4 presents carrot pressed skins, dried at different drying regimes. The analysis of images allows to make a conclusion that the use of vacuum and vibration at drying (Fig. 4 , $\boldsymbol{b})$ gives a possibility to get a product of better quality.

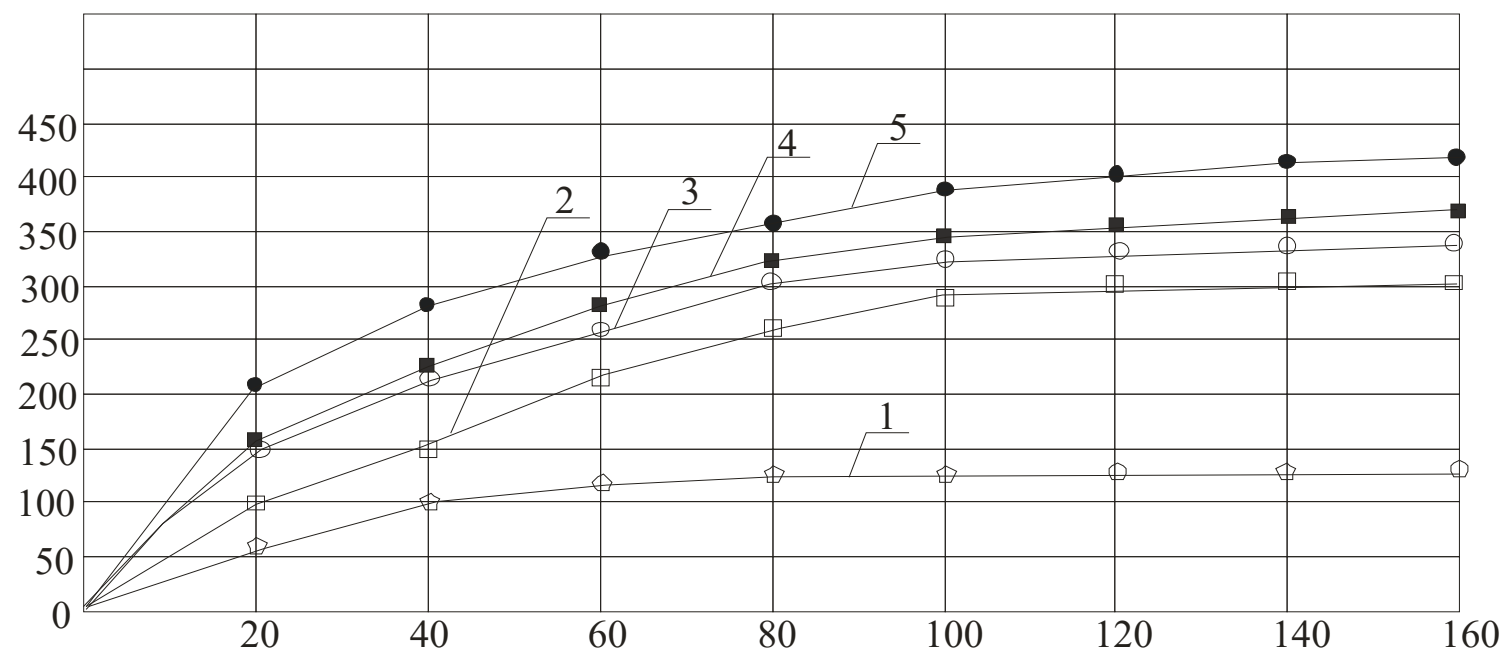

Fig. 3. Reproduction kinetics of carrot pressed skins depending on drying regimes (Table 1): 1 -regime $1 ; 2$-regime $2 ; 3$ - regime $3 ; 4$-regime $4 ; 5$ - regime 5 


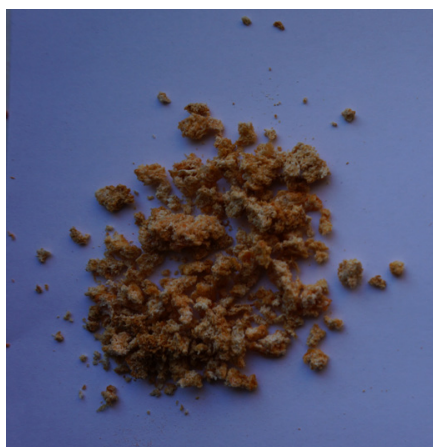

$a$

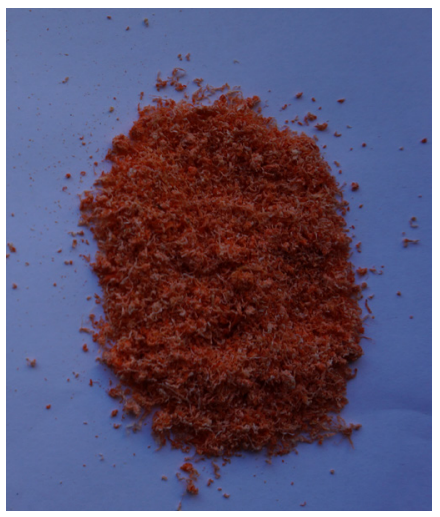

$b$

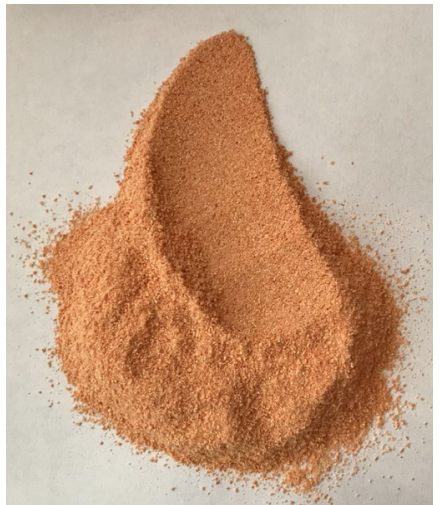

$c$

Fig. 4. Carrot pressed skins, dried at different drying regimes: $a$-without using vibration; $b$ - using vibration; $c$-dried pressed skins after additional comminution

\section{Results}

The experimental studies of reproduction of carrot pressed skins have proved an advantage of drying methods for the raw materials under the influence of vibration that confirmed the choice of process parameters, namely amplitude and frequency. At that the experiment results prove perspectives of using dried pressed skins, obtained in such a way as a structure-former and filler of different food products. It gives a possibility to influence the output of products, their moisture and food value.

\section{Conclusions}

As a result of the conducted work, the production method for carrot vegetable concentrate, providing separate concentrating of liquid and solid fraction, has been elaborated. 
The technological production line has been designed according to the proposed method.

The vacuum vibration dryer construction for process realization has been developed.

The experimental studies of the swelling degree, solubility and reproduction of vegetable pressed skins have proved an advantage of drying raw materials under the influence of vibration that confirmed the choice of process parameters.

Vegetable pressed skins at using vibration and vacuum have the swelling degree by $120 \ldots 170 \%$ more than at the convection drying regime.

According to the research results, the solubility of vegetable pressed skins at the drying regimes using vibration and vacuum is by $300 \ldots 480 \%$ more than at the convection drying regime.

\section{References}

[1] Kochetkova, A. A., Tuzhilkin, V. I. (2003). Funktsional'nye pishchevye produkty: nekotorye tehnologicheskie podrobnosti v obshchem voprose. Pishchevaya promyshlennost', 5, 8-10.

[2] Rostovskyi, V. S., Oleinyk, N. V. (2009). Prohresyvni resursozberihaiuchi tekhnolohii v kharchoviy promyslovosti. Kyiv: Kondor, 136.

[3] Yezhov, V. M., Valuiko, H. H., Lukanin, O. S., Klechak, I. R. (1993). Biotekhnolohichni osnovy vyrobnytstva bilka i pektynu Z vidkhodiv pererobky plodiv ta vynohradu. Kyiv: Urozhai, 120.

[4] Nistor, O.-V., Seremet (Ceclu), L., Andronoiu, D. G., Rudi, L., Botez, E. (2017). Influence of different drying methods on the physicochemical properties of red beetroot ( Beta vulgaris L. var. Cylindra ). Food Chemistry, 236, 59-67. doi: https://doi.org/ 10.1016/j.foodchem.2017.04.129

[5] Osetskyi, A. I., Holtsev, A. M., Sevastianov, S. S. (2019). Sushinnia biolohichnoi syrovyny v rezhymi kriosublimatsiynoho fraktsionuvannia. VI Vsukr. naukovo-prakt. konf. «Problemy enerhoefektyvnosti ta yakosti v protsesakh sushinnia kharchovoi syrovyny». Kharkiv, 29-31.

[6] Zahorulko, A., Zagorulko, A., Fedak, N., Sabadash, S., Kazakov, D., Kolodnenko, V. (2019). Improving a vacuum-evaporator with enlarged heat exchange surface for making fruit and vegetable semi-finished products. Eastern-European Journal of Enterprise Technologies, 6 (11 (102)), 6-13. doi: https://doi.org/10.15587/1729-4061.2019.178764

[7] Zahorulko, A., Zagorulko, A., Kasabova, K., Shmatchenko, N. (2020). Improvement of zefir production by addition of the developed blended fruit and vegetable pasteinto its recipe. Eastern-European Journal of Enterprise Technologies, 2 (11 (104)), 39-45. doi: https://doi.org/10.15587/1729-4061.2020.185684

[8] Pohozhykh, M. I., Pak, A. O., Pak, A. V., Zherebkin, M. V. (2014). Hidrotermichna obrobka krup iz vykorystanniam pryntsypiv sushinnia zmishanym teplopidvodom. Kharkiv: KhDUKhT, 170.

[9] Sardarov, A., Mayak, O., Shevchenko, A., Prasol, S., Shershnev, G. (2018). Iinfluence of main technological parameters of drying on quality of bagasse from carrot and beet. EUREKA: Life Sciences, 5, 62-70. doi: https://doi.org/10.21303/2504-5695.2018.00732

[10] Sardarov, A., Mayak, O., Shershnev, G. (2018). Research of structural characteristics and kinetics of drying process raw material in vibration vacuum dryer. Scientific Works of National University of Food Technologies, 24 (6), 110-118. doi: https:// doi.org/10.24263/2225-2924-2018-24-6-15 